\title{
Rapid and effective oxidative pretreatment of woody biomass at mild reaction conditions and low oxidant loadings
}

Zhenglun Li $\mathrm{i}^{1,2}$, Charles H Chen ${ }^{1,2}$, Eric L Hegg ${ }^{2,3^{*}}$ and David B Hodge ${ }^{1,2,4,5^{*}}$

\begin{abstract}
Background: One route for producing cellulosic biofuels is by the fermentation of lignocellulose-derived sugars generated from a pretreatment that can be effectively coupled with an enzymatic hydrolysis of the plant cell wall. While woody biomass exhibits a number of positive agronomic and logistical attributes, these feedstocks are significantly more recalcitrant to chemical pretreatments than herbaceous feedstocks, requiring higher chemical and energy inputs to achieve high sugar yields from enzymatic hydrolysis. We previously discovered that alkaline hydrogen peroxide (AHP) pretreatment catalyzed by copper(II) 2,2'-bipyridine complexes significantly improves subsequent enzymatic glucose and xylose release from hybrid poplar heartwood and sapwood relative to uncatalyzed AHP pretreatment at modest reaction conditions (room temperature and atmospheric pressure). In the present work, the reaction conditions for this catalyzed AHP pretreatment were investigated in more detail with the aim of better characterizing the relationship between pretreatment conditions and subsequent enzymatic sugar release.

Results: We found that for a wide range of pretreatment conditions, the catalyzed pretreatment resulted in significantly higher glucose and xylose enzymatic hydrolysis yields (as high as $80 \%$ for both glucose and xylose) relative to uncatalyzed pretreatment (up to $40 \%$ for glucose and $50 \%$ for xylose). We identified that the extent of improvement in glucan and xylan yield using this catalyzed pretreatment approach was a function of pretreatment conditions that included $\mathrm{H}_{2} \mathrm{O}_{2}$ loading on biomass, catalyst concentration, solids concentration, and pretreatment duration. Based on these results, several important improvements in pretreatment and hydrolysis conditions were identified that may have a positive economic impact for a process employing a catalyzed oxidative pretreatment. These improvements include identifying that: (1) substantially lower $\mathrm{H}_{2} \mathrm{O}_{2}$ loadings can be used that may result in up to a 50-65\% decrease in $\mathrm{H}_{2} \mathrm{O}_{2}$ application (from $100 \mathrm{mg} \mathrm{H}_{2} \mathrm{O}_{2} / \mathrm{g}$ biomass to $35-50 \mathrm{mg} / \mathrm{g}$ ) with only minor losses in glucose and xylose yield, (2) a 60\% decrease in the catalyst concentration from $5.0 \mathrm{mM}$ to $2.0 \mathrm{mM}$ (corresponding to a catalyst loading of $25 \mu \mathrm{mol} / \mathrm{g}$ biomass to $10 \mu \mathrm{mol} / \mathrm{g}$ biomass) can be achieved without a subsequent loss in glucose yield, (3) an order of magnitude improvement in the time required for pretreatment (minutes versus hours or days) can be realized using the catalyzed pretreatment approach, and (4) enzyme dosage can be reduced to less than $30 \mathrm{mg}$ protein/g glucan and potentially further with only minor losses in glucose and xylose yields. In addition, we established that the reaction rate is improved in both catalyzed and uncatalyzed AHP pretreatment by increased solids concentrations.

(Continued on next page)
\end{abstract}

\footnotetext{
* Correspondence: erichegg@msu.edu; hodgeda@egr.msu.edu

${ }^{2}$ DOE Great Lakes Bioenergy Research Center, Michigan State University, East Lansing, USA

'Department of Chemical Engineering and Materials Science, Michigan State

University, East Lansing, USA

Full list of author information is available at the end of the article
} 
(Continued from previous page)

Conclusions: This work explored the relationship between reaction conditions impacting a catalyzed oxidative pretreatment of woody biomass and identified that significant decreases in the $\mathrm{H}_{2} \mathrm{O}_{2}$, catalyst, and enzyme loading on the biomass as well as decreases in the pretreatment time could be realized with only minor losses in the subsequent sugar released enzymatically. Together these changes would have positive implications for the economics of a process based on this pretreatment approach.

Keywords: Biofuels, Bioenergy, Chemical pretreatment, Hybrid poplar, Copper, Cu(bpy), Lignin, Oxidation, Hydrogen peroxide

\section{Introduction}

As the global demand for energy grows, the need for a sustainable fuel supply as a supplement or replacement for fossil fuels is becoming imperative [1]. Among possible technology options, the biochemical conversion of plantderived sugars to biofuels has the potential to displace a substantial fraction of gasoline. This biochemical route involves the enzymatic hydrolysis of plant-derived polysaccharides to monomeric sugars, followed by fermentation of these sugars to biofuels such as ethanol. Starch from corn grain has been a major source of sugars for ethanol production in the U.S., but significant future growth of the corn ethanol industry is limited by the growing demand for both food and animal feed, as well as the recent achievement of maximum production limits on starchbased ethanol set by the Renewable Fuel Standard in the Energy Independence and Security Act of 2007 [2]. Thus, cellulosic biomass (i.e. plant cell wall material) is envisioned as an important feedstock for producing biofuel sustainably in the future as well as meeting renewable transportation fuel mandates.

Woody biomass is an especially attractive alternative to corn as a feedstock for biofuels. In particular, shortrotation woody bioenergy crops such as willow (Salix spp.) and hybrid poplar (Populus spp.) that are currently grown in temperate regions for combined heat and power bioenergy applications represent important feedstocks for liquid transportation fuels with agronomic and logistical advantages. Specifically, it has been shown that hybrid poplar can be grown on marginal agricultural lands with low energy and chemical input and produce biomass with high energy density at moderately high productivities $[3,4]$, thereby providing significant motivation for developing effective and economic conversion technologies that can be coupled with woody feedstocks.

Due to the higher order structures in the plant cell wall, a chemical, thermal, or physical pretreatment step is necessary to facilitate the biochemical production of biofuels from plant cell wall polysaccharides. This need for pretreatment is primarily a consequence of cell wall lignin that limits cellulolytic enzyme accessibility to polysaccharides, with this cell wall recalcitrance to conversion especially problematic for the cell walls of woody plants. A wide range of pretreatments are known that differ in chemistry and mechanism but share the same outcome of increasing the accessibility of cell wall polysaccharides to cellulolytic enzymes [5]. Alkaline hydrogen peroxide (AHP) pretreatment is one such approach that has been studied since the 1980s [6-8]. AHP results in significant improvement in the enzymatic digestibility of commelinid monocots including corn stover and wheat straw $[9,10]$ and can generate hydrolysates with more than $100 \mathrm{~g} / \mathrm{L}$ of monomeric sugars that are fermentable without detoxification (manuscript in preparation). The mechanisms by which AHP pretreatment reduces recalcitrance include the fragmentation and solubilization of ester-linked xylan and lignin $[11,12]$, as well as the oxidation, solubilization, and at high $\mathrm{H}_{2} \mathrm{O}_{2}$ loadings, mineralization of lignin [7]. While effective at increasing enzymatic digestibility, however, the majority of previous work employed high $\mathrm{H}_{2} \mathrm{O}_{2}$ loadings (i.e. $>250 \mathrm{mg} / \mathrm{g}$ biomass) that would be economically challenging to implement industrially due to the high cost of $\mathrm{H}_{2} \mathrm{O}_{2}$ [6,7], and it is well-established that oxidative delignification using $\mathrm{H}_{2} \mathrm{O}_{2}$ treatment under alkaline conditions requires high $\mathrm{H}_{2} \mathrm{O}_{2}$ loadings to realize significant lignin removal from wood pulps [13].

Relative to herbaceous monocots, woody biomass such as hybrid poplar presents special challenges for AHP because of its thicker cell walls, denser vascular structure, and higher lignin content $[14,15]$. As a result, the improvement in enzymatic digestibility after AHP pretreatment is limited $[16,17]$, and this lack of efficacy on woody biomass is a ubiquitous challenge faced by many pretreatment methods $[5,18,19]$. Although a few methods including organosolv, dilute acid, and SPORL (a sulfite pretreatment combined with mechanical size reduction) have been reported to be effective pretreatments for hybrid poplar [20,21], all of these methods still have drawbacks such as a high consumption of chemicals and the generation of fermentation inhibitors [22]. As a result, there is great interest in identifying effective pretreatments for woody biomass.

In nature, plant cell walls can be biologically altered, catabolized, or degraded by plant pathogens and saprophytes including basidiomycetes [23], ascomycetes [24], and bacteria $[25,26]$. The strategies used by these organisms include the release of reactive oxygen species produced by 
redox-active metals and metalloenzymes [27] as well as the excretion of species-dependent combinations of lignin-modifying oxidoreductases [28-31], monooxygenases [32], and glycan-acting hydrolases, esterases, and lyases. Several abiotic catalytic oxidative treatments that mimic certain features of these successful biological approaches have recently been investigated as technologies for pulp bleaching or delignification [33,34] and the pretreatment of cellulosic biomass for the production of biofuels [35,36]. Leskelä and co-workers developed a pressurized $\mathrm{O}_{2}$ dependent strategy catalyzed by copper-diimine complexes that is effective in both pretreatment processes and pulp bleaching [36-38]. Another effective biomimetic approach reported by Lucas et al. uses oxidation by $\mathrm{H}_{2} \mathrm{O}_{2}$ catalyzed by manganese acetate to improve the hydrolysis yield from poplar sawdust [39].

We previously reported that AHP pretreatment catalyzed by copper(II) 2,2'-bipyridine complexes (Cu(bpy)) can result in significant improvements in the enzymatic digestibility of a number of biomass feedstocks including switchgrass, silver birch, and most notably hybrid poplar [35]. The improved cellulose digestibility correlated with increased lignin removal as well as modifications to cellulose that included oxidative depolymerization, the introduction of carboxylate groups, and the solubilization and/ or oxidative degradation of only up to $5 \%$ of the glucan in the original biomass. In the present manuscript we describe our investigation into the key parameters that impact the effectiveness of $\mathrm{Cu}$ (bpy)-catalyzed AHP pretreatment on hybrid poplar heartwood as quantified by glucose and xylose release during the subsequent enzymatic digestion of the pretreated biomass. Importantly, we report that the presence of catalytic amounts of $\mathrm{Cu}$ (bpy) during AHP pretreatment greatly improves process performance and decreases the required $\mathrm{H}_{2} \mathrm{O}_{2}$ loading, pretreatment time, enzyme loading, and hydrolysis time. Together, these reduced inputs result in significantly lower pretreatment costs and provide a compelling strategy for an improved pretreatment process for woody biomass.

\section{Results and discussion}

The key factors that influence the effectiveness of $\mathrm{Cu}$ (bpy)-catalyzed AHP pretreatment are reactant concentrations, catalyst concentrations, and reaction times. These variables not only strongly influence the extent of sugar release, but also greatly affect the overall economics of the pretreatment process. For example, lower $\mathrm{H}_{2} \mathrm{O}_{2}$ and enzyme concentrations result in decreased raw material costs while increased reaction rates lower capital costs associated with reactor volume due to decreased residence time. The initial $\mathrm{pH}$ for uncatalyzed AHP is 11.5 (the approximate $\mathrm{p} K_{\mathrm{a}}$ of $\mathrm{H}_{2} \mathrm{O}_{2}$ ), thereby largely defining the required $\mathrm{NaOH}$ loading. Therefore, in this work we focused on $\mathrm{H}_{2} \mathrm{O}_{2}$, biomass, and $\mathrm{Cu}$ (bpy) loadings, and how these variables affect pretreatment times, the required enzyme loading, and subsequent sugar release during saccharification.

To identify a potential lower limit for $\mathrm{H}_{2} \mathrm{O}_{2}$ during $\mathrm{Cu}$ (bpy)-catalyzed AHP, the effect of $\mathrm{H}_{2} \mathrm{O}_{2}$ loading on the subsequent enzymatic glucose and xylose yield of pretreated hybrid poplar was tested (Figure 1). These results demonstrate that while there is only minimal improvement in glucose and xylose yields with increasing $\mathrm{H}_{2} \mathrm{O}_{2}$ loadings for uncatalyzed AHP, the presence of catalytic amounts of $\mathrm{Cu}(\mathrm{bpy})$ results in monomeric glucose yields of more than $80 \%$ and monomeric xylose yields of more than $70 \%$ at the highest $\mathrm{H}_{2} \mathrm{O}_{2}$ loading $(100 \mathrm{mg} / \mathrm{g}$ biomass) after $72 \mathrm{~h}$ of hydrolysis. Importantly, these results demonstrate that the $\mathrm{H}_{2} \mathrm{O}_{2}$ loading can be halved (from 100 to $50 \mathrm{mg} / \mathrm{g}$ biomass) with less than a $4 \%$ decrease in the $72 \mathrm{~h}$ glucose and xylose yields. Additionally, the trend predicts that the $\mathrm{H}_{2} \mathrm{O}_{2}$ loading could be further decreased to as low as $35 \mathrm{mg} / \mathrm{g}$ biomass (comparable to loadings used in commercial pulp bleaching sequences $[40,41]$ ) and still result in more than $70 \%$ glucose yields for $72 \mathrm{~h}$ of hydrolysis. Considering that the cost of $\mathrm{H}_{2} \mathrm{O}_{2}$ would likely be one of the primary contributions to the raw materials costs, (along with biomass feedstock, enzyme, and catalyst cost) this $50-65 \%$ decrease in the $\mathrm{H}_{2} \mathrm{O}_{2}$ loading is substantial. For instance, based on a $\mathrm{H}_{2} \mathrm{O}_{2}$ cost of $\$ 1000 /$ ton, this $65 \%$ reduction in peroxide loading would decrease the $\mathrm{H}_{2} \mathrm{O}_{2}$ cost from $\$ 0.305 / \mathrm{kg}$ of total sugar generated to only $\$ 0.081 / \mathrm{kg}$.

The concentration of the $\mathrm{Cu}$ (bpy) catalyst utilized during pretreatment is another variable that can be optimized. This water-soluble metal complex has many advantages including its ease of synthesis from $\mathrm{CuSO}_{4}$ and 2,2'bipyridine [42] and the fact that it is small enough to diffuse into nanoscale pores within plant cell walls to perform catalysis in situ. Reducing $\mathrm{Cu}$ (bpy) loadings would be advantageous because this would reduce input costs, alleviate potential copper inhibition to the fermentation microorganism, and diminish environmental concerns about the fate of the catalyst in process water treatment streams. To this end, we tested the effect of catalyst loading on the enzymatic digestibility of pretreated hybrid poplar (Figure 2). Our results demonstrate that after $24 \mathrm{~h}$ pretreatment at $20 \%$ solids loading, the glucose and xylose yields both essentially saturate at a $\mathrm{Cu}$ (bpy) concentration of $2.0 \mathrm{mM}$ (corresponding to a catalyst loading of $10 \mu \mathrm{mol} / \mathrm{g}$ biomass) regardless of the hydrolysis time. In addition, the catalyst concentration can be further halved to $1.0 \mathrm{mM}(5.0 \mu \mathrm{mol} / \mathrm{g}$ biomass $)$ with only a $10 \%$ loss in the $72 \mathrm{~h}$ glucose yield (Figure $2 \mathrm{~A}$ ) and essentially no loss in the xylose yield (Figure 2B).

Importantly, the loading of catalyst on the basis of biomass can be decreased still further by increasing the solids concentrations during pretreatment while keeping the catalyst concentration constant (Table 1, Figure 3). 

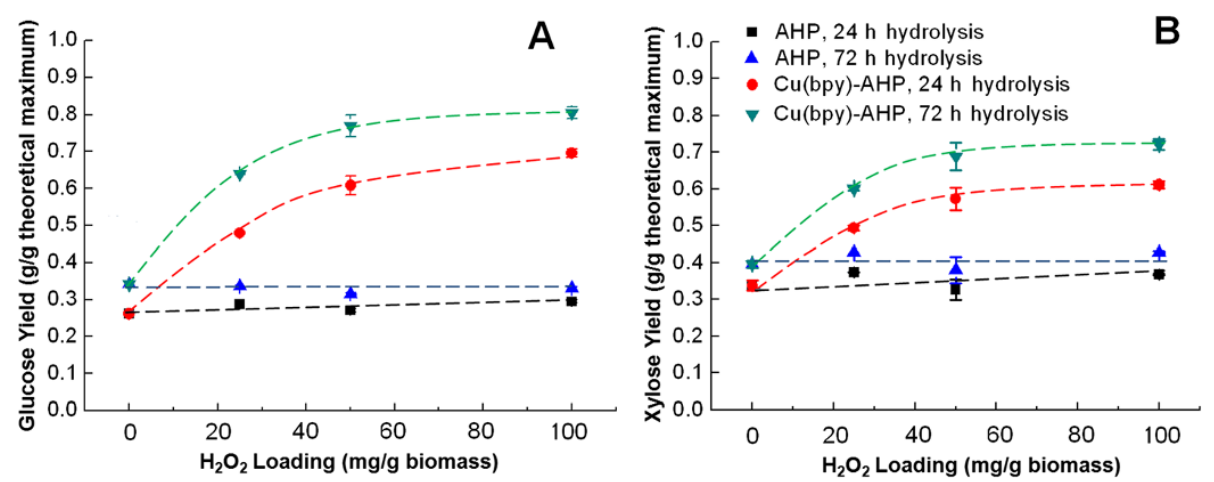

Figure 1 Effect of $\mathrm{H}_{2} \mathrm{O}_{2}$ loading during pretreatment on enzymatic hydrolysis yields. Results for (A) glucose and (B) xylose demonstrate that yields approach their saturation values near an $\mathrm{H}_{2} \mathrm{O}_{2}$ loading of $50 \mathrm{mg} / \mathrm{g}$ of biomass for $\mathrm{Cu}(\mathrm{bpy})$-catalyzed AHP pretreatment. Pretreatment was performed for $24 \mathrm{~h}$ at $10 \%(\mathrm{w} / \mathrm{v})$ solids with catalyzed pretreatment employing $2.0 \mathrm{mM}$ catalyst concentration.

Performing pretreatment and hydrolysis at high solids concentrations with no subsequent washing imparts a number of process benefits, including a decrease of process water usage, a decrease in required reactor volumes, and an increase in sugar titers from hydrolysis and subsequent ethanol titers from fermentation. Intriguingly, uncatalyzed AHP pretreatment shows a noticeable increase in glucan and xylan digestibilities as the hybrid poplar solids are increased from $10 \%$ to $20 \%$ (w/v), with further modest increases continuing even up to $50 \%(\mathrm{w} / \mathrm{v})$ solids concentration. The catalyzed AHP pretreatment shows a different trend in that the maximum enzymatic digestibility of hybrid poplar is achieved for solids concentrations in the range of $10 \%$ to $20 \%(\mathrm{w} / \mathrm{v})$ solids with pretreatment efficacy decreasing above $30 \%$ solids (w/v) concentration. We suspect that at higher solids concentrations $(>20 \% \mathrm{w} / \mathrm{v})$, the efficacy of the catalyzed pretreatment may be affected by limited mass transfer due to the lack of free water [43], decreased selectivity of $\mathrm{H}_{2} \mathrm{O}_{2}$ for the biomass versus disproportionation due to the change in reactant concentrations, and/or the decrease in catalyst loading on the biomass (decreasing to $4.0 \mu \mathrm{mol} / \mathrm{g}$ biomass).

Pretreatment reaction kinetics is important for the economics of a process since reactor volume and hence capital equipment requirement is proportional to the residence time of the reactor. An advantage of $\mathrm{Cu}$ (bpy)catalyzed AHP pretreatment is that the pretreatment time is significantly shorter than for uncatalyzed pretreatment. In fact, the enzymatic glucan yield of pretreated poplar rapidly increases to approach a near maximum value within only $10-30$ min pretreatment time at $10 \%$ solids $(\mathrm{w} / \mathrm{v})$ concentrations, while increasing the solids to $20 \%$ $(\mathrm{w} / \mathrm{v})$ results in achieving the maximum value in less than 10 min (Figure 4A). Comparable increases in the xylan yields can also be achieved within the same short period of time (Figure 4B). Conversely, uncatalyzed AHP pretreatment results in considerably lower yield improvements and requires significantly longer pretreatment time for maximum efficacy.
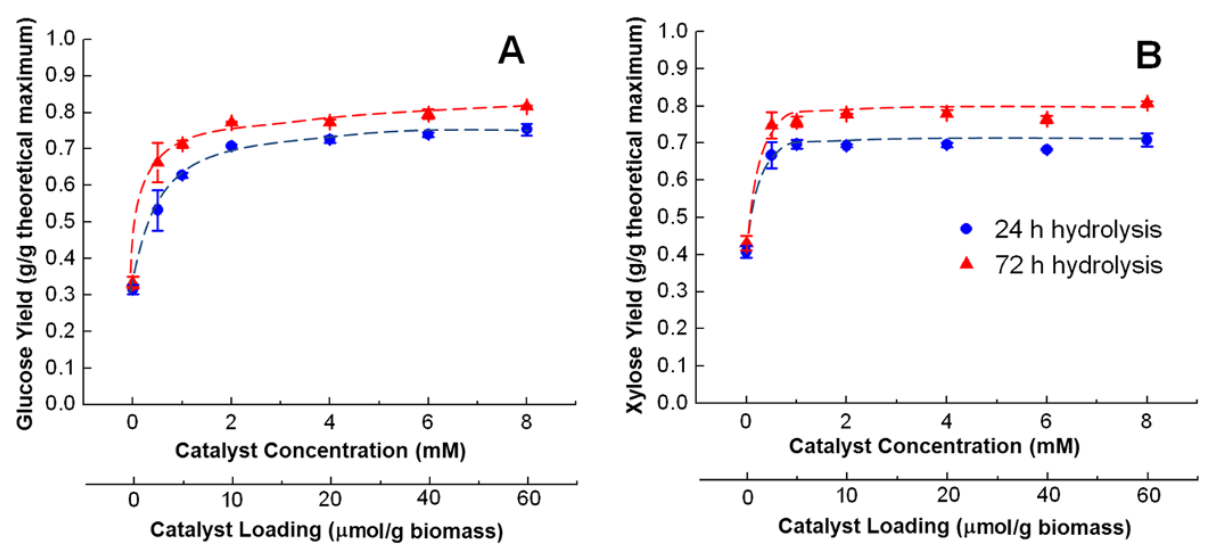

Figure 2 Effect of catalyst concentration during $\mathrm{Cu}(\mathrm{bpy})$-AHP pretreatment on the enzymatic hydrolysis yields. Results for (A) glucose and (B) xylose, demonstrate that yields approach their saturation values near a Cu(bpy) concentration of $2 \mathrm{mM}$ (or 10 umol/g biomass). Pretreatment was performed for $24 \mathrm{~h}$ at a solids concentration of $20 \%(\mathrm{w} / \mathrm{v})$ and a $100 \mathrm{mg} / \mathrm{g} \mathrm{H}_{2} \mathrm{O}_{2}$ loading on the biomass. 
Table 1 Chemical inputs used for pretreatment of $\mathbf{5 0 0} \mathbf{~ m g}$ biomass at different solids concentrations

\begin{tabular}{ccccc}
\hline $\begin{array}{c}\text { Insoluble solids } \\
\text { concentration }(\mathbf{w} / \mathbf{v})\end{array}$ & $\begin{array}{c}\text { Liquid } \\
\text { volume }(\mathbf{m L})\end{array}$ & $\begin{array}{c}\text { Cu catalyst } \\
\text { loading on biomass }(\boldsymbol{\mu m o l} / \mathbf{g})^{\mathbf{a}}\end{array}$ & $\begin{array}{c}\mathbf{H}_{2} \mathrm{O}_{2} \text { loading on } \\
\text { biomass }(\mathbf{m g} / \mathbf{g})\end{array}$ & $\begin{array}{c}\text { NaOH loading on } \\
\text { biomass }(\mathbf{m g} / \mathbf{g})\end{array}$ \\
\hline $10 \%$ & 5.00 & 20 & 100 & 108 \\
$20 \%$ & 2.50 & 10 & 100 & 108 \\
$30 \%$ & 1.67 & 6.67 & 100 & 108 \\
$40 \%$ & 1.25 & 5 & 100 & 108 \\
$50 \%$ & 1.00 & 4 & 100 & 108 \\
\hline
\end{tabular}

${ }^{\mathrm{a}}$ In all cases the catalyst concentration is $2.0 \mathrm{mM}$.

In addition to employing enzymatic hydrolysis as a screen for determining the differences in pretreatment conditions, we also investigated both enzyme loading and xylanase supplementation for their impact on glucan and xylan yields. While an extensive optimization of enzyme cocktail was not performed, several enzyme loadings and cellulase:xylanase ratios were tested, with the results presented in Figure 5. This shows that the improvement in sugar yield between catalyzed and uncatalyzed pretreatment is significant for all enzyme loadings tested, but the greatest absolute difference is at the higher enzyme loadings. Furthermore, it can be observed that substantially less enzyme is needed to achieve higher digestibilities (i.e. less mass enzyme protein per mass sugar generated) using $\mathrm{Cu}(\mathrm{bpy})$-catalyzed AHP treated poplar relative to the AHP pretreated material. Another observation is that the xylanase supplementation provides improvement in both the glucose and xylose yields with the synergy between xylanases and cellulases increased at limiting enzyme loadings (Figure 5). This indicates that, like other xylan-retaining pretreatments, xylanase leveraging is possible [44], although the optimal ratios cannot be established from this data. While this was not a complete enzyme cocktail optimization, these results indicate that for the given pretreatment conditions, glucan and xylan yields nearly saturate at their maximum achievable levels with respect to enzyme loading. Additionally, the enzyme dosage can be decreased by at least a $50 \%$ total enzyme loading of $30 \mathrm{mg}$ protein/g glucan (at a 15:15 cellulase: xylanase ratio) with only minor losses in glucose and xylose yields. This relatively high enzyme loading could likely be decreased further if a full optimization were performed. This decrease is important considering that enzyme costs are anticipated to be one of largest contributions to cellulosic biofuels costs [45].

The kinetics of the enzymatic hydrolysis for catalyzed and uncatalyzed pretreatment during pretreatment was also investigated (Figure 6), highlighting a number of important outcomes of the pretreatments. As demonstrated above, both the rate and extent of enzymatic hydrolysis are significantly improved following $\mathrm{Cu}(\mathrm{bpy})$-catalyzed AHP treatment relative to uncatalyzed treatment. After 3 hours of hydrolysis, the enzymatic yields of glucose in $\mathrm{Cu}$ (bpy)-catalyzed AHP pretreated poplar is approximately two-fold higher than that in hybrid poplar after uncatalyzed AHP pretreatment, and this ratio increases even further with longer hydrolysis time. Another key finding is that while longer pretreatment times result in higher monomeric glucose yields for both catalyzed and uncatalyzed AHP pretreatment, the majority of the glucose yield improvement by pretreatment takes place within the first 30 minutes. Additionally, the differences in sugar yield between $1 \mathrm{~h}$ and $24 \mathrm{~h}$ pretreatment times
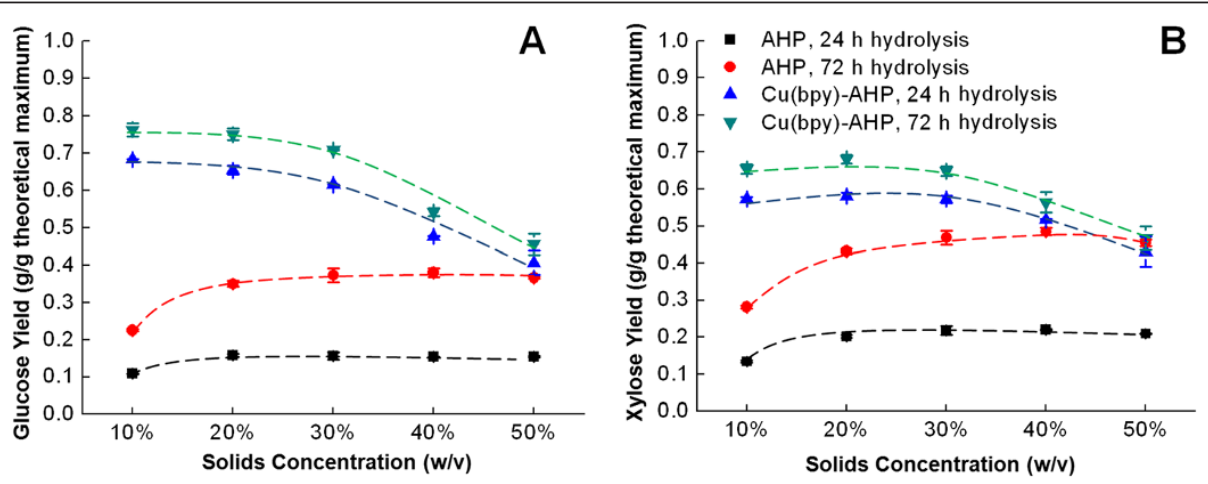

Figure 3 Effect of solids concentrations during pretreatment on enzymatic hydrolysis yields. The data for (A) glucose and (B) xylose, demonstrate inverse trends for $\mathrm{Cu}(\mathrm{bpy})$-AHP versus uncatalyzed AHP. Pretreatment was performed for $24 \mathrm{~h}$ at $100 \mathrm{mg} \mathrm{H}_{2} \mathrm{O}_{2}$ per gram of biomass with catalyzed pretreatment employing $2.0 \mathrm{mM}$ catalyst concentrations. 

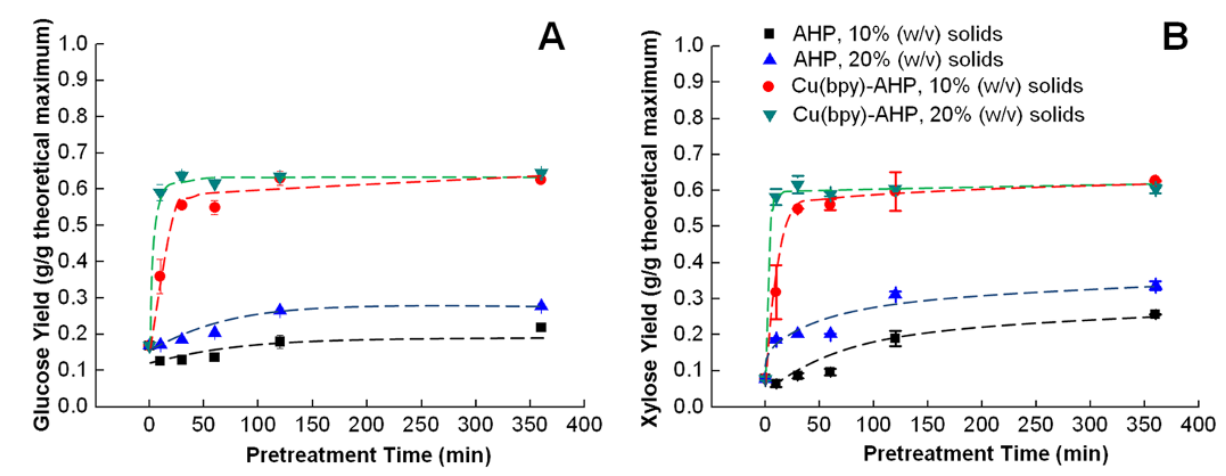

Figure 4 Effect of pretreatment time and solids concentration on enzymatic hydrolysis yields. The pretreatment kinetics showing enzymatic (A) glucose and (B) xylose release for catalyzed pretreatments were performed with $2.0 \mathrm{mM}$ catalyst concentrations and $100 \mathrm{mg} \mathrm{H}_{2} \mathrm{O}_{2}$ per gram of biomass, and the hydrolysis was performed for $24 \mathrm{~h}$.

nearly disappear at $20 \%$ solids, in agreement with previous results (Figure 4).

For both catalyzed and uncatalyzed AHP pretreatment, the xylose hydrolysis yields are highly correlated with the glucose hydrolysis yields (Figures 1, 2, 3, 4, 5 and 6). In fact, there is an almost perfect linear correlation (R-squared greater than 0.99) between glucose and xylose release for most conditions of $\mathrm{Cu}(\mathrm{bpy})$-catalyzed AHP (Additional file 1: Figure S1A) with a slope of 1.5 , meaning that every $15 \%$ increase in glucose yield corresponds to a $10 \%$ increase in xylose yield. This can be contrasted to uncatalyzed AHP pretreatment of hybrid poplar which results in lower yields of both glucose and xylose (less than $35 \%$ and $50 \%$ respectively), a weaker correlation (R-squared values ranging from 0.70 to greater than 0.99 for individual data sets), and slopes in the range of 0.60 to 0.85 (Additional file 1: Figure S1B). We speculate that these differences may have implications for both the mechanisms of pretreatment and its impact on the cell wall structure.
In general terms, improvements in enzymatic yields can be understood as cell wall alterations that provide hydrolytic enzymes greater accessibility to the cell wall matrix polysaccharides, and these differences in glucose versus xylose released may be interpreted as differences in how the pretreatments alter the polysaccharide accessibility to enzymes. Specifically, enzyme accessibility for cellulose hydrolysis is known to be dependent on xylan removal in conjunction with lignin removal or relocalization in diverse woody and herbaceous angiosperms. This relationship between xylan removal and cellulose hydrolysis has been shown for both dilute acid [46] and AHP [11] pretreatments, as well as during enzymatic hydrolysis whereby increased xylanase supplementation is well-known to increase the glucose yields for biomass where a significant fraction of the xylan is retained during pretreatment [44]. This is reasonable considering that xylan is believed to sheath the surface of cellulose microfibrils and modulate its interactions with other cellulose microfibrils as well as other cell
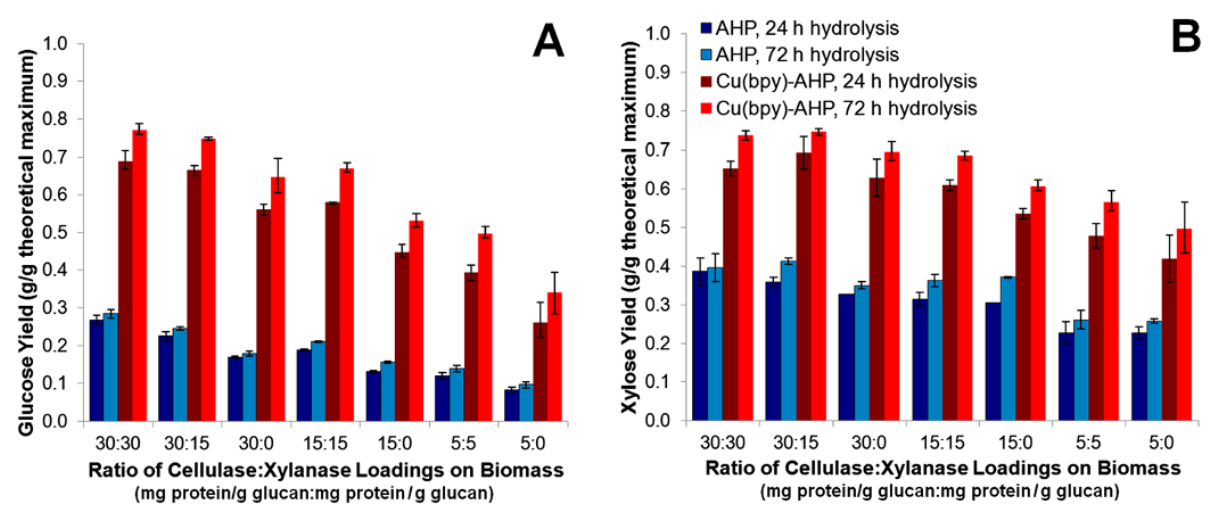

Figure 5 Effect of enzyme loading and xylanase supplementation on enzymatic hydrolysis yields. The results for (A) glucose and (B) xylose compare AHP and $\mathrm{Cu}(\mathrm{bpy})$-catalyzed AHP pretreatment performed for $24 \mathrm{~h}$ with $100 \mathrm{mg} \mathrm{H}_{2} \mathrm{O}_{2}$ per gram of biomass, 10\% (W/v) solids concentration, and a Cu(bpy) concentration of $2.0 \mathrm{mM}$ for the catalyzed reaction. 

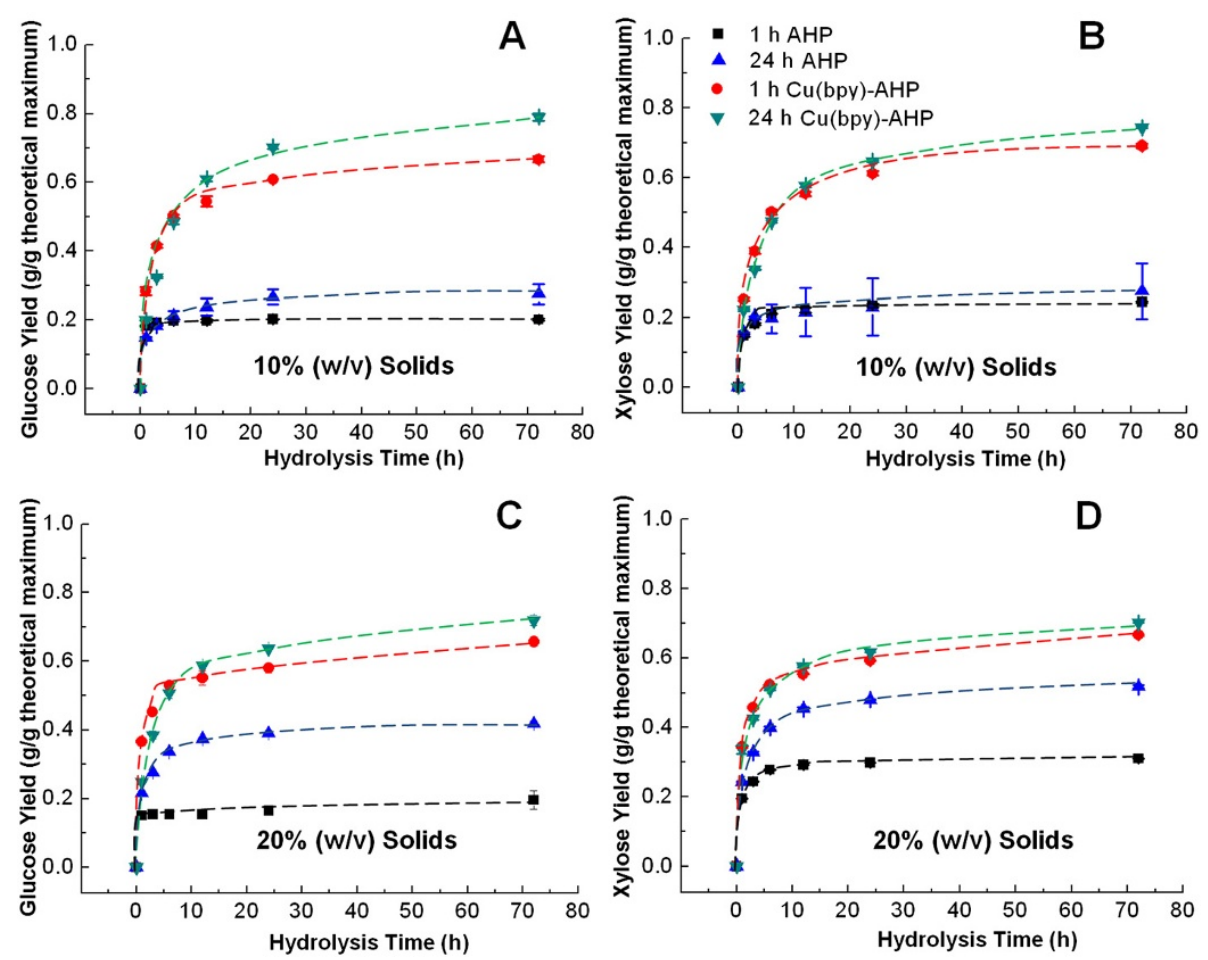

Figure 6 Enzymatic hydrolysis kinetics for uncatalyzed and Cu(bpy)-catalyzed AHP. The data show yields of glucose and (A and C) and xylose (B and $\mathbf{D}$ ) and the solids concentrations (w/v) during pretreatment are 10\% (A and $\mathbf{B}$ ) and 20\% (C and $\mathbf{D})$. Pretreatment was performed for $24 \mathrm{~h}$ with $100 \mathrm{mg} \mathrm{H} \mathrm{H}_{2}$ per gram of biomass at a catalyst concentration of $2.0 \mathrm{mM}$ for $\mathrm{Cu}(\mathrm{bpy})$-catalyzed AHP pretreatment.

wall matrix macromolecules [47]. We speculate that the uncatalyzed AHP pretreatment is only capable of removing easily accessible or easily extractable xylan and that only minor glucose hydrolysis yield improvements can be realized in this regime as the bulk of the cellulose may still be embedded within the lignified cell wall. The increase in the slope of the linear correlation in the high glucan digestibility regime (corresponding to pretreatment with $\mathrm{Cu}$ (bpy)-catalyzed AHP) can be interpreted as representing an enhanced total polysaccharide accessibility due to the action of pretreatment, whereby the increased accessibility of xylan and its hydrolysis results in an increase in cellulose hydrolysis. As shown in our previous work [35], this enhancement in polysaccharide accessibility during $\mathrm{Cu}$ (bpy)-catalyzed AHP pretreatment is possibly a consequence of improved lignin removal. Moreover, the depolymerization of lignocellulose macromolecules potentially disrupts cell wall structure, increases the area accessible to enzymes, and facilitates mass transfer during enzymatic hydrolysis.

\section{Conclusions}

In this work we characterized $\mathrm{Cu}(\mathrm{bpy})$-catalyzed AHP pretreatment conditions that resulted in significantly increased enzymatic saccharification yields for hybrid poplar heartwood. Relative to our previously reported results from an initial screening of catalysts and biomass feedstocks [35], here we describe a number of important improvements in this catalyzed pretreatment of woody biomass that will enable more efficient use of process inputs during pretreatment and enzymatic hydrolysis. These include significant decreases in the loading of $\mathrm{H}_{2} \mathrm{O}_{2}$ on biomass, catalyst concentrations, enzyme loadings, and pretreatment duration as well as an increase in solids concentrations. Importantly, it was found that the $\mathrm{H}_{2} \mathrm{O}_{2}$ loadings on biomass could be decreased to as low as 35-50 $\mathrm{mg} / \mathrm{g}$ without significant losses in sugar yield by enzymatic hydrolysis, bringing the oxidant loadings down into the range that may be employed in commercial pulp bleaching sequences. Future investigations on $\mathrm{Cu}(\mathrm{bpy})-$ catalzyed AHP pretreatment will focus on enhancing our mechanistic understanding of the catalyzed oxidation, characterizing the changes to cell wall polymers and solubilized organics, and improving process integration with fermentation.

\section{Methods}

Chemical composition analysis of hybrid poplar heartwood Heartwood from 18-year old hybrid poplar (Populus nigra var. charkoviensis x caudina cv. NE-19) grown at the University of Wisconsin Arlington Agricultural Research Station was hammermilled to pass through a $5 \mathrm{~mm}$ 
screen (Circ-U-Flow model 18-7-300, Schutte-Buffalo Hammermill, LLC). The initial composition of structural carbohydrates and acid-insoluble lignin (Klason lignin) were determined using the NREL two-stage acidolysis method [48] with modifications as described elsewhere [35].

\section{Catalytic AHP pretreatment}

Copper(II) 2,2'-bipyridine complexes were prepared in situ in an aqueous stock solution containing $15.6 \mathrm{~g} / \mathrm{L}$ $\mathrm{CuSO}_{4} \cdot 5 \mathrm{H}_{2} \mathrm{O}$ (EMD Chemicals, Billerica, MA) and 31.2 g/L 2,2' -bipyridine (Sigma-Aldrich, St. Louis, MO) to yield a molar ligand to metal (L:M) ratio of 5:1. Hybrid poplar ( $0.500 \mathrm{~g}$ dry basis; $3.0 \%$ moisture) was pretreated in a total of $5.0 \mathrm{~mL}$ aqueous solution containing 2.0 $\mathrm{mM} \mathrm{Cu}$ catalyst, $20.0 \mathrm{~g} / \mathrm{L} \mathrm{H}_{2} \mathrm{O}_{2}$, and $21.6 \mathrm{~g} / \mathrm{L} \mathrm{NaOH}$ for pretreatment at $10 \%$ solids. For pretreatment at different solids concentrations, a different volume of aqueous solution with the $2.0 \mathrm{mM} \mathrm{Cu}$ catalyst was used, while the doses of $\mathrm{H}_{2} \mathrm{O}_{2}$ and $\mathrm{NaOH}$ on the basis of biomass were the same (Table 1). After vortex mixing the reactants with the biomass, the slurry was incubated with orbital shaking at $180 \mathrm{rpm}$ at $30^{\circ} \mathrm{C}$ [35].

\section{Enzymatic hydrolysis}

After pretreatment, $20 \mu \mathrm{L}$ of $72 \%(\mathrm{w} / \mathrm{w}) \mathrm{H}_{2} \mathrm{SO}_{4}$ and 0.5 $\mathrm{mL}$ of $1 \mathrm{M}$ citric acid buffer ( $\mathrm{pH} 4.8$ ) were added to the pretreated slurry to adjust the $\mathrm{pH}$ to 5.0 , a level suitable for enzymatic hydrolysis. Next, $40 \mu \mathrm{L}$ of $10 \mathrm{mM}$ tetracycline (Sigma-Aldrich) stock solution was added to inhibit microbial growth, followed by addition of the enzyme cocktail consisting of Cellic CTec2 and HTec2 (Novozymes A/S, Bagsværd, DK) at a loading of $30 \mathrm{mg}$ protein/g glucan each on the untreated biomass unless otherwise noted. The total protein contents of enzyme cocktails used in determining enzyme loadings on biomass were quantified using the Bradford Assay (SigmaAldrich). The total volume was adjusted to $10 \mathrm{~mL}$ by the addition of deionized water, and the samples were incubated at $50^{\circ} \mathrm{C}$ with orbital shaking at $180 \mathrm{rpm}$. Following enzymatic hydrolysis, the solid and liquid phases were separated by centrifugation, and the amount of glucose and xylose released into the aqueous phase was quantified by HPLC (Agilent 1100 Series equipped with an Aminex HPX-87H column operating at $65^{\circ} \mathrm{C}$, a mobile phase of $0.05 \mathrm{M} \mathrm{H}_{2} \mathrm{SO}_{4}$, a flow rate of $0.6 \mathrm{~mL} / \mathrm{min}$, and detection by refractive index) [35]. The yield of glucose and xylose released was defined as the amount of solubilized monosaccharide divided by the total sugar content of the biomass prior to pretreatment as determined by chemical composition analysis [48]. While xylan is solubilized during pretreatment, no monomeric sugars were detected in the pretreatment liquor. Error bars in figures represent the data range between biological replicates.

\section{Additional file}

Additional file 1: Figure S1. Replotting data from Figures 1 and 6 demonstrating different trends in glucose and xylose yield between catalyzed (A) and uncatalyzed (B) AHP pretreatment.

\section{Abbreviations}

AHP: Alkaline hydrogen peroxide; Cu(bpy): Copper(II)-2,2'-bipyridine complexes; HPLC: High performance liquid chromatography.

\section{Competing interests}

The authors declare that they have no competing interests.

\section{Authors' contributions}

$\mathrm{DBH}, \mathrm{ELH}$ and $\mathrm{ZL}$ conceived the work, ZL, CHC, DBH, and ELH wrote the manuscript, $\mathrm{CHC}$ performed the pretreatment, composition analysis and enzymatic digestibility analysis. All authors provided input and corrections to the manuscript. All authors read and approved the final manuscript.

\section{Acknowledgments}

This work was funded by the DOE Great Lakes Bioenergy Research Center (DOE BER Office of Science DE-FC02-07ER64494).

\section{Author details}

${ }^{1}$ Department of Chemical Engineering and Materials Science, Michigan State University, East Lansing, USA. ²DOE Great Lakes Bioenergy Research Center, Michigan State University, East Lansing, USA. ${ }^{3}$ Department of Biochemistry \& Molecular Biology, Michigan State University, East Lansing, USA. ${ }^{4}$ Department of Biosystems \& Agricultural Engineering, Michigan State University, East Lansing, USA. ${ }^{5}$ Department of Civil, Environmental and Natural Resources Engineering, Luleå University of Technology, Luleå, Sweden.

Received: 22 April 2013 Accepted: 20 August 2013

Published: 26 August 2013

\section{References}

1. Scheffran J: The Global Demand for Biofuels: Technologies, Markets and Policies. In Biomass to Biofuels. Edited by Vertès AA, Qureshi N, Blaschek HP, Yukawa H. Chichester, UK: John Wiley \& Sons Ltd; 2010:27-54.

2. Valentine J, Clifton-Brown J, Hastings A, Robson P, Allison G, Smith P: Food vs. fuel: the use of land for lignocellulosic 'next generation' energy crops that minimize competition with primary food production. GCB Bioenergy 2012, 4:1-19.

3. Walsh ME, Ugarte DGD, Shapouri H, Slinsky SP: Bioenergy crop production in the United States - Potential quantities, land use changes, and economic impacts on the agricultural sector. Environ Resour Econ 2003, 24:313-333.

4. Adler PR, Del Grosso SJ, Parton WJ: Life-cycle assessment of net greenhouse-gas flux for bioenergy cropping systems. Ecol Appl 2007, 17:675-691.

5. Kumar P, Barrett DM, Delwiche MJ, Stroeve P: Methods for pretreatment of lignocellulosic biomass for efficient hydrolysis and biofuel production. Ind Eng Chem Res 2009, 48:3713-3729.

6. Wei C-J, Cheng C-Y: Effect of hydrogen peroxide pretreatment on the structural features and the enzymatic hydrolysis of rice straw. Biotechnol Bioeng 1985, 27:1418-1426.

7. Gould JM: Alkaline peroxide delignification of agricultural residues to enhance enzymatic saccharification. Biotechnol Bioeng 1984, 26:46-52.

8. Gould JM, Jasberg BK, Fahey GC, Berger LL: Treatment of wheat straw with alkaline hydrogen peroxide in a modified extruder. Biotechnol Bioeng 1989, 33:233-236.

9. Qi B, Chen X, Shen F, Su Y, Wan Y: Optimization of enzymatic hydrolysis of wheat straw pretreated by alkaline peroxide using response surface methodology. Ind Eng Chem Res 2009, 48:7346-7353.

10. Banerjee G, Car S, Liu T, Williams DL, Meza SL, Walton JD, Hodge DB: Scaleup and integration of alkaline hydrogen peroxide pretreatment, enzymatic hydrolysis, and ethanolic fermentation. Biotechnol Bioeng 2012, 109:922-931. 
11. Li M, Foster C, Kelkar S, Pu Y, Holmes D, Ragauskas A, Saffron C, Hodge D: Structural characterization of alkaline hydrogen peroxide pretreated grasses exhibiting diverse lignin phenotypes. Biotechnol Biofuels 2012, 5:38.

12. Doner LW, Hicks KB: Isolation of hemicellulose from corn fiber by alkaline hydrogen peroxide extraction. Cereal Chem J 1997, 74:176-181.

13. Nguyen XT, Simard L: On the delignification of OCC with hydrogen peroxide, TAPPI International Pulp Bleaching Conference; 1996:569-576.

14. Zhai HM, Lee ZZ: Ultrastructure and topochemistry of delignification in alkaline pulping of wheat straw. J Wood Chem Technol 1989, 9:387-406.

15. Sperry JS: Evolution of water transport and xylem structure. Int J Plant SCi 2003, 164:S115-S127.

16. Gupta R, Lee YY: Pretreatment of corn stover and hybrid poplar by sodium hydroxide and hydrogen peroxide. Biotechnol Prog 2010, 26:1180-1186.

17. Ayeni AO, Hymore FK, Mudliar SN, Deshmukh SC, Satpute DB, Omoleye JA, Pandey RA: Hydrogen peroxide and lime based oxidative pretreatment of wood waste to enhance enzymatic hydrolysis for a biorefinery: Process parameters optimization using response surface methodology. Fuel 2013, 106:187-194.

18. Nguyen Q, Tucker M, Keller F, Eddy F: Two-stage dilute-acid pretreatment of softwoods. Appl Biochem Biotechnol 2000, 84-86:561-576.

19. Zhao Y, Wang Y, Zhu JY, Ragauskas A, Deng Y: Enhanced enzymatic hydrolysis of spruce by alkaline pretreatment at low temperature. Biotechnol Bioeng 2008, 99:1320-1328.

20. Wang ZJ, Zhu JY, Zalesny RS, Chen KF: Ethanol production from poplar wood through enzymatic saccharification and fermentation by dilute acid and SPORL pretreatments. Fuel 2012, 95:606-614.

21. Pan $X$, Xie D, Kang K-Y, Yoon S-L, Saddler J: Effect of organosolv ethanol pretreatment variables on physical characteristics of hybrid poplar substrates. Appl Biochem Biotechnol 2007, 137-140:367-377.

22. Dale BE, Ong RG: Energy, wealth, and human development: Why and how biomass pretreatment research must improve. Biotechnol Prog 2012, 28:893-898.

23. Baldrian $P$, Valášková V: Degradation of cellulose by basidiomycetous fungi. FEMS Microbiol Rev 2008, 32:501-521.

24. Fujii K, Sugimura T, Nakatake K: Ascomycetes with cellulolytic, amylolytic, pectinolytic, and mannanolytic activities inhabiting dead beech (Fagus crenata) trees. Folia Microbiol 2010, 55:29-34.

25. Warshaw JE, Leschine SB, Canaleparola E: Anaerobic cellulolytic bacteria from wetwood of living trees. Appl Environ Microbiol 1985, 50:807-811.

26. Wenzel M, Schönig I, Berchtold M, Kämpfer P, König H: Aerobic and facultatively anaerobic cellulolytic bacteria from the gut of the termite Zootermopsis angusticollis. J Appl Microbiol 2002, 92:32-40.

27. Kerem Z, Jensen KA, Hammel KE: Biodegradative mechanism of the brown rot basidiomycete Gloeophyllum trabeum: evidence for an extracellular hydroquinone-driven Fenton reaction. FEBS Lett 1999, 446:49-54.

28. Leonowicz A, Matuszewska A, Luterek J, Ziegenhagen D, Wojtaś-Wasilewska M, Cho N-S, Hofrichter M, Rogalski J: Biodegradation of lignin by white rot fungi. Fungal Genet Biol 1999, 27:175-185.

29. Wong DWS: Structure and action mechanism of ligninolytic enzymes. Appl Biochem Biotechnol 2009, 157:174-209.

30. Baldrian P: Fungal laccases - occurrence and properties. FEMS Microbio/ Rev 2006, 30:215-242.

31. Hatakka A: Lignin-modifying enzymes from selected white-rot fungi: Production and role from in lignin degradation. FEMS Microbiol Rev 1994, 13:125-135.

32. Béguin P, Aubert J-P: The biological degradation of cellulose. FEMS Microbiol Rev 1994, 13:25-58.

33. Rahmawati N, Ohashi Y, Honda Y, Kuwahara M, Fackler K, Messner K, Watanabe T: Pulp bleaching by hydrogen peroxide activated with copper 2,2'-dipyridylamine and 4-aminopyridine complexes. Chem Eng J 2005, 112:167-171.

34. Suchy M, Argyropoulos Dimitris S, American Chemical Society: Catalysis and Activation of Oxygen and Peroxide Delignification of Chemical Pulps: A Review, Oxidative Delignification Chemistry; 2001:2-43.

35. Li Z, Chen CH, Liu T, Mathrubootham V, Hegg EL, Hodge DB: Catalysis with Cu'(bpy) improves alkaline hydrogen peroxide pretreatment. Biotechnol Bioeng 2013, 110:1078-1086.

36. Korpi H, Lahtinen P, Sippola V, Krause O, Leskelä M, Repo T: An efficient method to investigate metal-ligand combinations for oxygen bleaching. Appl Catal A-Gen 2004, 268:199-206.
37. Hakola M, Kallioinen A, Kemell M, Lahtinen $P$, Lankinen $E$, Leskelä M, Repo T, Riekkola T, Siika-aho M, Uusitalo J, Vuorela S, von Weymann N: Liberation of cellulose from the lignin cage: A catalytic pretreatment method for the production of cellulosic ethanol. Chem Sus Chem 2010, 3:1142-1145.

38. Rovio S, Kallioinen A, Tamminen T, Hakola M, Leskelä M, Siika-aho M: Catalysed alkaline oxidation as a wood fractionation technique. BioRes 2012, 7:756-776

39. Lucas M, Hanson SK, Wagner GL, Kimball DB, Rector KD: Evidence for room temperature delignification of wood using hydrogen peroxide and manganese acetate as a catalyst. Bioresour Technol 2012, 119:174-180.

40. Bajpai P: ECF and TCF bleaching. In Environmentally Benign Approaches for Pulp Bleaching. Edited by Bajpai P. Amsterdam: Elsevier; 2005:177-192.

41. Xu E, Koefler $H$, Antensteiner P: Some latest developments in alkali peroxide mechanical pulping, Part 2: Low consistency secondary refining. Pulp Paper Canada 2003, 104:47-51

42. Garribba E, Micera G, Sanna D, Strinna-Erre L: The Cu(II)-2,2 '-bipyridine system revisited. Inorg Chim Acta 2000, 299:253-261.

43. Modenbach AA, Nokes SE: The use of high-solids loadings in biomass pretreatment-a review. Biotechnol Bioeng 2012, 109:1430-1442.

44. Kumar R, Wyman CE: Effect of xylanase supplementation of cellulase on digestion of corn stover solids prepared by leading pretreatment technologies. Bioresour Technol 2009, 100:4203-4213.

45. McMillan J, Jennings E, Mohagheghi A, Zuccarello M: Comparative performance of precommercial cellulases hydrolyzing pretreated corn stover. Biotechnol Biofuels 2011, 4:29.

46. Yang B, Wyman CE: Effect of xylan and lignin removal by batch and flowthrough pretreatment on the enzymatic digestibility of corn stover cellulose. Biotechnol Bioeng 2004, 86:88-98.

47. Reis D, Vian B, Roland J-C: Cellulose-glucuronoxylans and plant cell wall structure. Micron 1994, 25:171-187.

48. Sluiter A, Hames B, Ruiz R, Scarlata C, Sluiter J, Templeton D, Crocker D: Determination of structural carbohydrates and lignin in biomass, Technical Report NREL/TP; 2011:10-42618.

doi:10.1186/1754-6834-6-119

Cite this article as: Li et al:: Rapid and effective oxidative pretreatment of woody biomass at mild reaction conditions and low oxidant loadings. Biotechnology for Biofuels 2013 6:119.

\section{Submit your next manuscript to BioMed Central and take full advantage of:}

- Convenient online submission

- Thorough peer review

- No space constraints or color figure charges

- Immediate publication on acceptance

- Inclusion in PubMed, CAS, Scopus and Google Scholar

- Research which is freely available for redistribution

Submit your manuscript at www.biomedcentral.com/submit
C Biomed Central 